\title{
The Technological Economy Altering the Firms Limit: the GMO Soybeans in Brazil
}

\author{
Vitor Francisco Dalla Corte', Matheus Dhein Dill'
}

\begin{abstract}
Technological changes afforded a development in the agricultural productivity, making use of less resources and producing more out of it. Aiming to analyze if the boundaries the firm (soy producer) were altered due to technological changes (GMO soy). The evolution of soy production was compared and related to: the use of credit loans for covering costs; the amount of contracts related to rural loans; and the area for farming soy using rural credit. The results confirm the "Penrosian" conceptual, that the decreasing incomes may be overcome by the firm's capacity to adapt its structure to new production conditions. So, it is possible to state that soy producer in Brazil were benefited with the opportunities brought about by the technological economy.
\end{abstract}

Keywords: agricultural loan; agricultural productivity; transgenic.

'Center of Studies and Researches in Agribusiness (CEPAN), Federal University of Rio Grande do Sul (UFRGS).Av. Bento Gonçalves, 7.7I2, 91.540-000, Porto Alegre, RS, Brasil.Tel. +55 5 I 3308-6586. E-mail: vitordallacorte@gmail.com, matheusdill@hotmail.com. 


\section{Introduction}

Technological changes may alter the limits of the firm. This way, the organizational adaptations, before new technologies arising in a scenery of changes, directly interfere on its performance. As the firm grows, the reorganization of resources are necessary, new services/inputs that were not used before may be implemented. It is possible when increasing the knowledge about the physical attributes of these resources, as well as a way to use them, in other words, a new technology is developed (Penrose, 1959).

One of the major technological changes present in the agricultural sector is the inclusion of genetically modified organisms (GMO), known as transgenic. Currently, soybeans, corn, cotton and canola are the main GMO products offered on a worldwide commercial scale (ISAAA, 20I I).

In Brazil, production and marketing of GMO products were regulated in 2005, being the soybeans the first and main GMO product grown. Due to higher financial returns compared to conventional soybean production, many producers have opted to produce this type of soy (Osaka and Battle, 2007), making the country the second largest producer of GMO technology products (ISAAA, 20II).

The adoption of this technology may have allowed farmers a technological economy. Therefore, this study aimed to evaluate if the limit of the rural soy producer has suffered any alteration due to the technological change (the inclusion of GMO soybeans). To that purpose the evolution of soy production was compared to: the amount of credit for covering costs allowed to rural producers; the amount of loan contracts; and the financed soy area in Brazil within 2000 to 2010.

In the next sections it will be focused the concepts regarding the firm and its boundaries as well as the technological economy. Then it is shown how a technological change can alter the boundaries of a firm.

\section{The Firm, the Technological Economy and its Limits}

Davi Ricardo was one of the pioneers in the investigation about the labor and income from the land, having Adam Smith (1776) work as a base. To Ricardo (I8I7) the rural producers that would possess superior resources (more fertile lands) would be in advantage compared to the other producers. To increase the production there should increase the land area, bringing the rural property to a limit, and to alter this limit it could be necessary more capital. However, it would not be, necessarily, needed more land, considering that a new technology could enhance the production without expanding the land area and work, in other words, the limits of the firm can be altered.
In the Coase's (1937) theory of the firm, a firm would alter its limits when additional transactions would be organized by the entrepreneur. Changes related to an improvement of managerial techniques would cause the firm to expand its size. To the author the growth of a firm brings along with itself decreasing returns to the entrepreneur functions, existing a cost increase of the additional transactions.

So the firm would tend to expand to the level that the cost of an additional transaction would be the same as in the market, what would not justify the existence of a firm (Coase, 1937).

The author Penrose (1959) criticized Coase's theory, mainly regarding the limits inherent to the firm's size, which appear through the decreasing incomes from a certain production scale. According to the author, this theoretical supposition is able to ensure the consistence in the analysis of market equilibrium, where it is mandatory to explain the impossibility of expansion without production limits of a firm. Still to the author, this stream of thought of the "theory of the firm" does not address the firm, for the fact that it is a mere abstraction that needs more empirical coherence.

To determine the firm, Penrose (1959) recommends to open the "black box", defining the firm as a group of productive resources that may be combined and readjusted. This way, the conditions and the pace of the firm's growth may show decreasing incomes, however these incomes may be altered through the capacity and the ability of the managerial structure to adapt to new ways of production and commerce.

The term of the firm's growth, according to Penrose (1959), is used in two ways. It may be related to the quantitative increase, as for example, the increase of production, sales, exports. On the other side, qualitative, used to address the expansion on size or the quality improvement, resulting from internal changes that cause the firm to expand. The firm's growth is related to the efficient use of the productive resources, essentially constituted by opportunities. These opportunities will become limited as the firm does not realize, or does not want to use them, or is unable to make use of them for its own growth.

As the firm grows it becomes necessary the specialization of work, with the purpose of rearranging the resources in a more efficient way. With the possibility of using new services/inputs, that were not used before, the firms only started to use them when they broadened their knowledge about the characteristics of these resources, as well as the way to use them (Penrose, 1959).

This evolutionary process of the firm growth (quantitative and qualitative) is related to the cumulative increment of the

ISSN: 07 I8-2724. (http://www.jotmi.org)

Journal of Technology Management \& Innovation @ Universidad Alberto Hurtado, Facultad de Economía y Negocios. 
collective wisdom (Penrose, 1959). The ceaseless process searching for a new alternative that provides advantages, will promote internal structural changes, substituting the old structure for a new one (Schumpeter, 1942).

A new structure can emerge from a technological economy, that according to Penrose (1959) means that once established the price of the productive resources, an increase in the production scale would allow an alteration of the productive techniques as well as the resources used, which in turn can reduce the average cost of products. The firms that make use of the technological economies will be able to produce to lower costs when compared to firms that do not use them. So, it is possible to elucidate that the firms that adopt the technological economies in an efficient way will rule the segment they are in.

Thus, the technological economy arises as the costs can be reduced through the labor force specialization; introduction of machinery and equipment; new techniques, and appropriate inputs that can produce larger amounts at lower costs. So, the size of a "technically excellent" firm may be due to the technologies adopted as well as the price of the productive resources used (Penrose, 1959).

Therefore, not always a change for an input that allows a production increase will bring about positive results. In this case, the accretion in the production cost is higher than the results of the scale elevation. On the other side, if the same resources were cheaper, an increase in the productive scale will allow a production at lower costs (Penrose, 1959).

The firm that can capture the market signals and mobilize knowledge to respond to these signals, by offering products and services, may obtain a sustained positioning in the market. But to obtain this positioning, it is necessary to analyze if investments are going to be demanded and how they can alter the firm's limit.

\section{Material and Method}

To verify if a technological change may alter the boundaries of a firm, the soybeans itself is focused, due to its representation in the agribusiness segment and the insertion of the GMO in 2005 in Brazil. The analysis of the firm's boundaries (soybeans producer) was performed through the comparison between variables related to the soy production and cost, as well as the measurement of productivity indexes that relate the production and the costs within the period of 2000 to 2010 . The first variable considered was the production expressed in tons. The data was obtained at the Companhia Nacional de Abastecimento - CONAB (20II). variable of costing. In Brazil, rural credit loans cover all the resources related to expenses, investments and marketing. The expenses aims to cover all the production cycle ordinary costs, from purchasing inputs till the harvesting. Therefore, the investment credit is applied to durable goods and services, whose benefits can be observed for many years. At last, the credit designated to commercialization aims to ensure the rural producer and its cooperatives price guarantees.

To infer about the firm's limit the credit for expenses (seeds, fertilizers and agrochemicals) was defined as the second variable. This variable was chosen due to its asset specificity regarding the analyzed object. Investments in machinery and storage could distort the analysis, instead of using these resources to other crops and agricultural activities.

The available monetary resources are expressed in Reais, and the data was obtained at Banco Central do Brasil $B C B(20 \mathrm{II})$ in the statistical rural credit yearbooks. As it is a series of monetary values, in order to obtain the present value, the data was deflated using the General Price Index (IGP - DI), calculated by Fundação GetúlioVargas during the analyzed period of time.After the comparison between production and the expense credit, it was carried out the credit productivity index, when relating the soybeans production with the variable of expense credit, as can be seen on equation I.

$$
\operatorname{Pcr}(\mathrm{t})=\operatorname{Ps}(\mathrm{t}) / \mathrm{Cc}(\mathrm{t})
$$

\section{Considering:}

$\mathrm{Pcr}=$ credit loans productivity during the period of time $t$

$\mathrm{Ps}_{\mathrm{s}}=$ soybeans production in the period of time $\mathrm{t}$

$\mathrm{Cc}=$ expense credit loans in the period of time $t$

Thus, the higher the productivity index, the larger would be the firm's limit expansion without resizing the organizational structure. As a complement, a third and a fourth variables were inserted in the analysis, regarding the number of contracts and the total financed area (hectare) allowed for soybeans production costs. Both data were also obtained in the BCB's statistical rural credit yearbooks. Comparatives between the third and the fourth variables with the soy production in the period were carried out and calculated the number of contracts productivity index and the total financed area using the same method from equation I, replacing the expenses credit for the number of contracts and the financed area.

For the analysis purpose the rural credit was defined as a

ISSN: 07I 8-2724. (http://www.jotmi.org)

Journal of Technology Management \& Innovation (C) Universidad Alberto Hurtado, Facultad de Economía y Negocios. 


\section{Technological Change in the Rural Production}

World population growth, concomitant to the improvement of incomes, especially in developing countries, generated challenging conditions to meet the global demand for agricultural products. In this perspective, the Green Revolution was triggered in the late 1960/1970, which promoted the increase of food production through the creation of technology packages developed by research centers. Genetic studies have been held in order to develop plants resistant to water scarcity and nutrients, pests and diseases. No less important has been the technological advances congruous to agricultural implements (machines, tractors and sprinklers) and also the development of fertilizers and pesticides. These advances resulting from technological changes have provided an evolution in terms of productivity, becoming necessary to use less resources to produce more food. Due to the increasing use of technology the biotech crop area increased by 80 times between 1996 and 2009, becoming one of the world's most widely adopted technologies in the recent history of agriculture (ISAAA, 20I I).

One of the main biotechnologies developed were the genetically modified organisms- GMO. In 1996, cotton was the commodity with higher representation inherent to GMO, corresponding for $29 \%$ of the total cultivated area, followed by soybeans with $18 \%$, by corn with $11 \%$, canola and other crops accounted for $39 \%$ of world production. In 200I, soybeans became responsible for most of the global area planted with GMO, with nearly $58 \%$, a position that remains above $58 \%$ in 2009 (ISAAA, 20I I).

In 2009, 25 countries have used the biotechnologies, I5 are developing countries versus 10 industrialized countries. Each of the eight leading countries grew more than I million of hectares of GMO crops: USA (64 millions of hectares), Brazil $(2 \mathrm{I}, 4)$,Argentina $(2 \mathrm{I}, 3)$, India $(8,4)$, Canada $(8,2)$, China $(3,7)$, Paraguay $(2,2)$ and South Africa $(2, I)$ (ISAAA, 20I I).

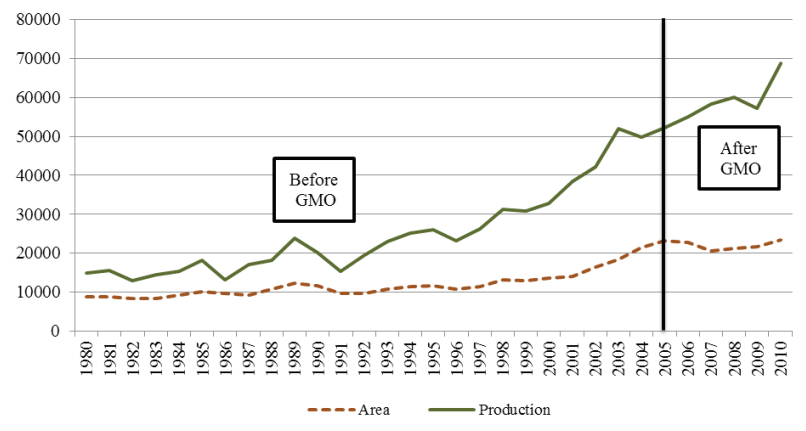

Brazil is the second largest producer of biotechnological crops on a global level, as described above, with an increase of 5.6 millions hectares of GMO crops, surpassing, albeit by a narrow margin, Argentina. It represents the largest absolute growth in hectares compared to other countries, representing a 35\% growth between 2008 and 2009 (James, 2009).

Due to the expressive soybeans representation in Brazil the high adoption rate of soybean GMO RRC from 2005, the insertion of this crop features a technological change that will be addressed in the subsequent sections.

\section{The Soybean and the GMO in Brazil}

The soy reached Brazil via United States in 1882. In 1900 and 1901, the Agronomic Institute of Campinas, SP, distributed the soybean seeds to producers of San Paulo. In this same period Rio Grande do Sul also planted this leguminous, that found favorable conditions to develop and expand, due to resemblance with the origin ecosystem climate, southern of USA (EMBRAPA, 2004).

In mid 1950, the soybean crop was encouraged for being the best alternative in the summer to succeed the wheat cultivated in the winter, both from a technical and economical point of view. The soy cultivation starts to increase in 1960 along with the wheat, in Rio Grande do Sul, due to the more rational use of agricultural equipment and soil management. An increase in the cultivated area to other regions in the following decades, as well as the expansion of this crop in the pioneer regions, awarded the soybeans a high representation in the Brazilian export of agricultural products. Figure I shows the evolution of production, area and productivity of soybean in Brazil.

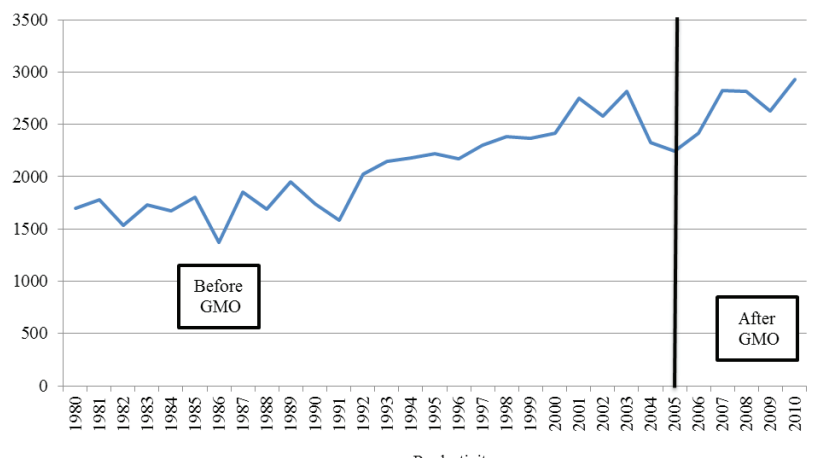

Figure I.Area, production and productivity of soybean in Brazil. SOURCE: CONAB (20I I)

ISSN: 07 I8-2724. (http://www.jotmi.org)

Journal of Technology Management \& Innovation @ Universidad Alberto Hurtado, Facultad de Economía y Negocios. 
It can be observed in Figure I a significant increase in the production of this cereal, but also an evolution in the cultivated area in a lower rate. So, the soy productivity which in 1980 was $178 \mathrm{l} \mathrm{kg} /$ hectare in 2010 reached $2927 \mathrm{~kg} /$ hectare, a nearly $65 \%$ increase. Thus it is possible to infer that there was an increase in production but not necessarily an acreage increase in the same proportion.

Although the production and commerce of GMO products already existed in other countries, its growth authorization in Brazil was subject to discussions. In 1995 the CTNBio (National Technical Commission of Biosafety) was created by the Law 8.9743 , with the purpose to technologically analyze all the activities developed by using genetic engineering. In 1996, Monsanto had seeds undergoing testing in research fields located in a state of Brazil, Rio Grande do Sul. Other research centers, Empresa Brasileira de Pesquisas Agropecuárias (Embrapa) and biotechnology laboratories at Universidade Federal do Rio Grande do Sul (UFRGS) were also making strides in the genetic manipulation of vegetable species using non-traditional methods (Daroit and Nascimento, 2009).

In 1998, CTNBio issued an opinion favorable to the cultivation of GMO soybean, however IDEC and Greenpeace appealed to the Federal Court and prevented the cultivation of this oilseed. But in 2005 was enacted the Law n $n^{\circ} 11.092$ which established the rules for the planting and marketing of genetically modified soybeans. The adaptation of certain varieties of GMO soybeans drew the producers' attention due to their higher productivity if compared to the conventional soy (Osaki and Batalha, 2007).

In 2009 , GMO soybean accounted for more than $65 \%$ of the total acreage of soy in Brazil. According to Céleres (20l I) until 2018 projections estimate that this percentage will raise to $90 \%$.
It is worth to note that the easiness of weed control, less agrochemical use, the possibility to apply the herbicide at any time in the crop cycle, harvesting in a clean area, and the financial economy to carry out the weed control are one of the reasons that motivate the producers to join this technology (Osaki and Batalha, 2007).

Through this review it is evident to notice that a technological change has occurred (the use of GMO soy). In the following item it will be analyzed the soy production evolution, the use of credit for costing the activities inherent to the soy production, the amount of contracts related to rural loans, and the total area used for the soy planting in order to answer the following question: Has the adoption of a new technology (GMO soy) altered the limits of a rural firm?

\section{Technological Change and the Alteration of a Firm's Limit}

It is known that the necessity of credit in order to afford the agricultural activity is essential for its growth, in other words, the expansion of the firm's limit. The premise of this research is that the rural producers have limited resources, and need a financing to acquire, even that partially, a certain amount of inputs for the production.

In 2010 in Brazil, more than $\mathrm{R} \$ 8 \mathrm{I}$ billion has been released for rural loans. Most of this credit was made available by federal banks, and account for more than $75 \%$ of the total financed amount. Much of this money was used to cover expenses related to the agricultural activity, as shown in Figure 2 .

As a delimitation for this research, it has been chosen the specific costing of the soybean, area that account for most of these resources, to express the rural firm's need for financ-

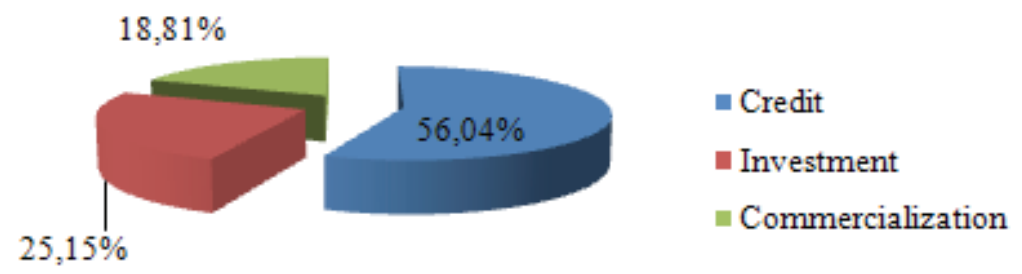

Figure 2. Rural Loans in Brazil for 2010. Source: BCB (201I)

ISSN: 07I 8-2724. (http://www.jotmi.org)

Journal of Technology Management \& Innovation (c) Universidad Alberto Hurtado, Facultad de Economía y Negocios. 
ing. Thus, the higher the necessity for funding, the lower is the producer's capacity, considering that the same levels of production are maintained. So it is necessary the comparative analysis between production development and costing. See Figure 3.

It can be observed on figure 3 that the soy production has increased in the analyzed period of time, and the rural firms may have become more efficient due to the technological change, given the reduced need for credit loans, before the production increase. This reduction is more expressive in the beginning of the technological change when takes place the higher credit loans productivity in 2006, but a reduction of this productivity rate can be observed in the following years.

Thus, it is possible to infer that a change in technology has altered the limits of a firm. This fact is directly related to the inclusion of genetically modified soybeans in 2005. The use of this new technology has allowed the firm's growth regarding the volume of soybeans production, which occurred without an increase in the need for credit loans.
Complementing the analysis, the Figure 4 presents a comparison between the production of the soybeans and the amount of contracts. Similar tendencies have been observed, which means, there is a higher increase in production than in the number of contracts. The productivity contracts index increased from 2005 and for three consecutive years, and remains stable in the following years, in a higher level previous to the technological change.

When relating the credit loan to the number of contracts it is observed that both suffered reductions, in other words, there was no further spread of contracts with the reduction in the amount of both.

Another result is presented on Figure 5, a comparative between the production soybean and the financed area. It happens the same as observed on the Figures 3 and 4, corroborating the statement of a production increase higher than the increase in the financed area, as well as an increase in the productivity area index, in the four years subsequent to the technological change.
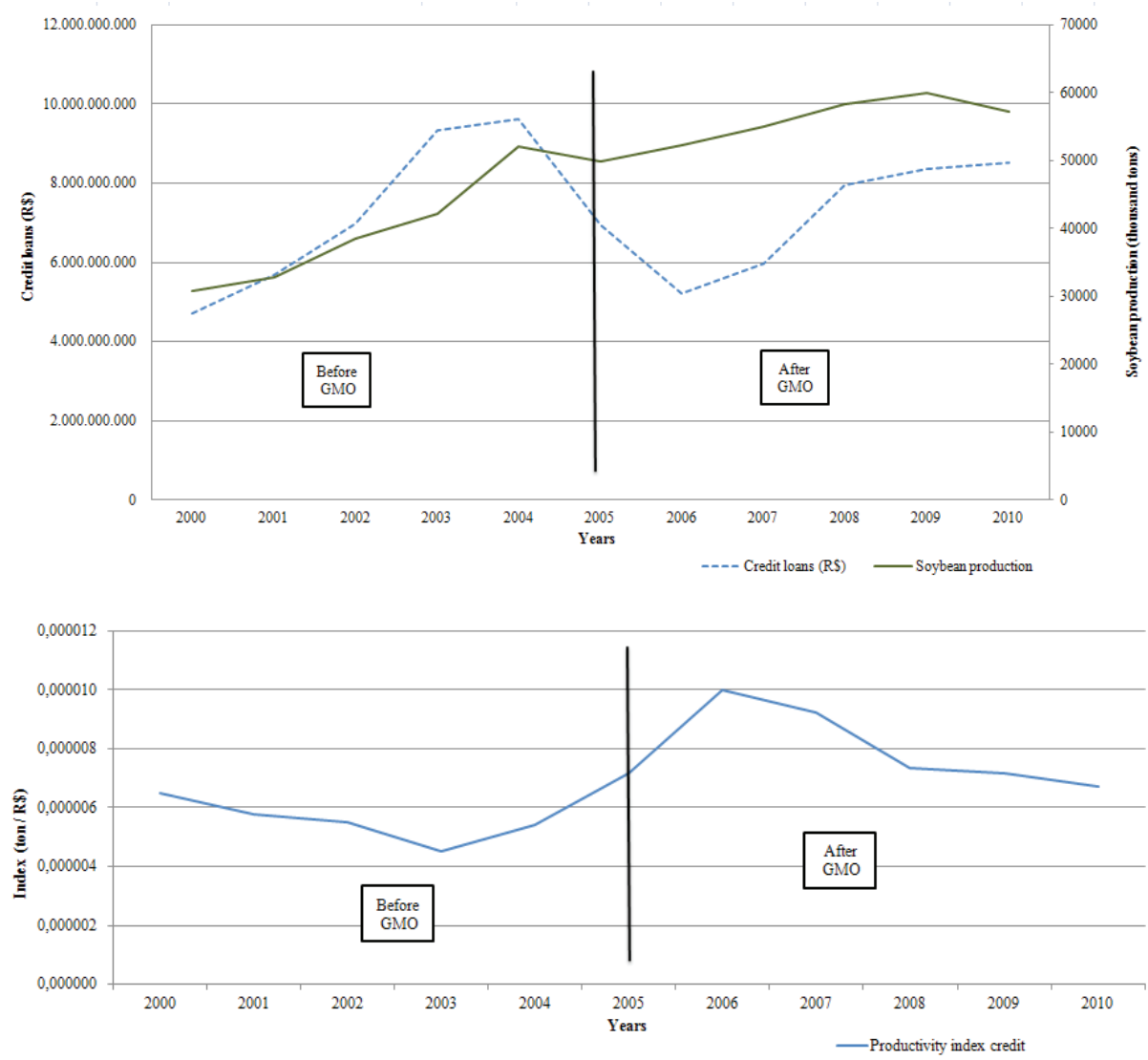

Figure 3. Credit loan, soybean production and productivity loans index. Source: BCB, CONAB (20II)

ISSN: 07 I8-2724. (http://www.jotmi.org)

Journal of Technology Management \& Innovation (c) Universidad Alberto Hurtado, Facultad de Economía y Negocios. 
Figure 4. Number of contracts, soybean production and comparative between soy production and number of contracts. Source: BCB, CONAB (20II)
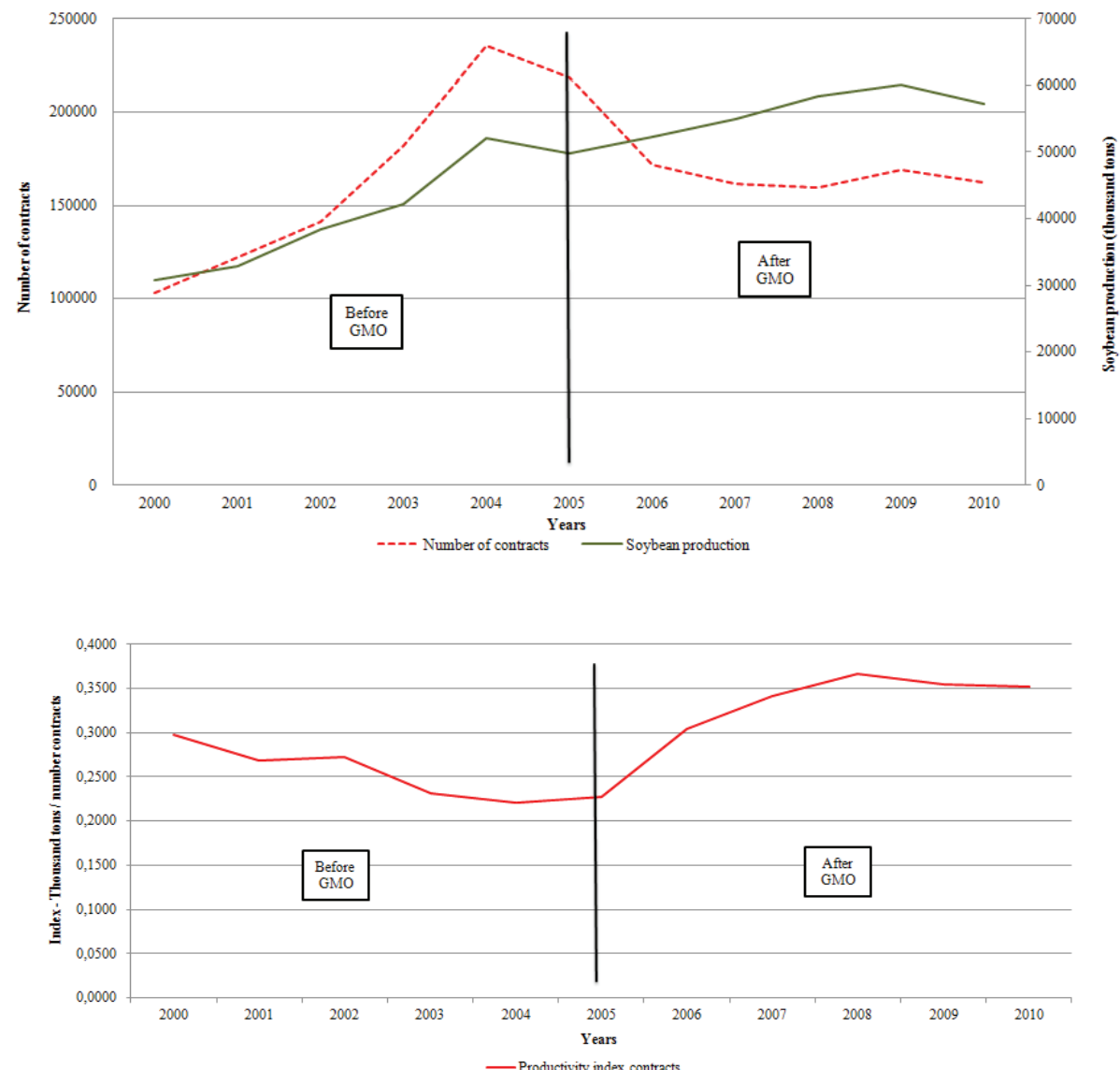

This way, the use of a new technology as the GMO RRC soybean, may have allowed an expansion in production volumes without a necessarily expansion in the organizational structure, which means, the firm grows quantitatively (production) with no need of more financial assistance.

So, the growth pace of a rural firm could have decreasing returns, though this income may be being modified through the entrepreneur's ability and capacity to adapt to new forms of production. In this study, the technological economy described by Penrose (1959), arises to the extent that costs can be reduced through the use of new techniques and better inputs to produce more with lower costs, expanding the firm's limits.

Soon, arises the technological economy through the use of the RR() soybeans. According to Céleres (20l I), this technology allowed a reduction in the amount of products used in the soy production, as well as a reduction in the number of pulverization when compared to the conventional system, and also a reduction of active ingredients (agrochemicals) per hectare. In this context, of tech change, Osaki and Batalha (2007) corroborate stating that the average operational margin with the use of RRC soybean was of $972 \mathrm{R} \$ /$ hectare while the conventional soy was $910 \mathrm{R} \$ /$ hectare in 2009, representing a 6,85\% technological economy.

In accordance with the analysis, it is possible to evidence that the use of GMO soy reduced the spending on manpower, facilitating the control and fight against weeds (Bonny, 2003). As a consequence the work time applied for the execution of these tasks has also reduced. In turn, farmers need less capital investment because they spend less on labor and employees management.

\section{Conclusions}

From the change in technology, it can be observed an alteration in the soybean producer firm's limit in Brazil. The herein study corroborated Penrose's (1959) statements, in

ISSN: 07 I8-2724. (http://www.jotmi.org) 
which the limits of the firm's growth do not necessarily occur according to the premise of the decreasing income. The research also shares the same viewpoint of Ricardo (1817), who states that an agricultural improvement may elevate the production without, necessarily, expanding the land territory. It has been verified that in soy production, a new technology, allowed a technological economy with the production increase without, necessarily, increasing the funding on its different indexes, such as: number of contracts, financed area, costing, and the productivity indexes of the variables.

So, it is possible for the firm to grow and not decrease its incomes. What allows it to happen is to open the firm's "black box" in order that the productive resources may be rearranged. It means that the decreasing incomes may be overcome by the firm's capacity to alter/adapt its structure to new production conditions, in other words, the soybeans rural producer firm in Brazil has adapted to a new technology and its limit was altered.
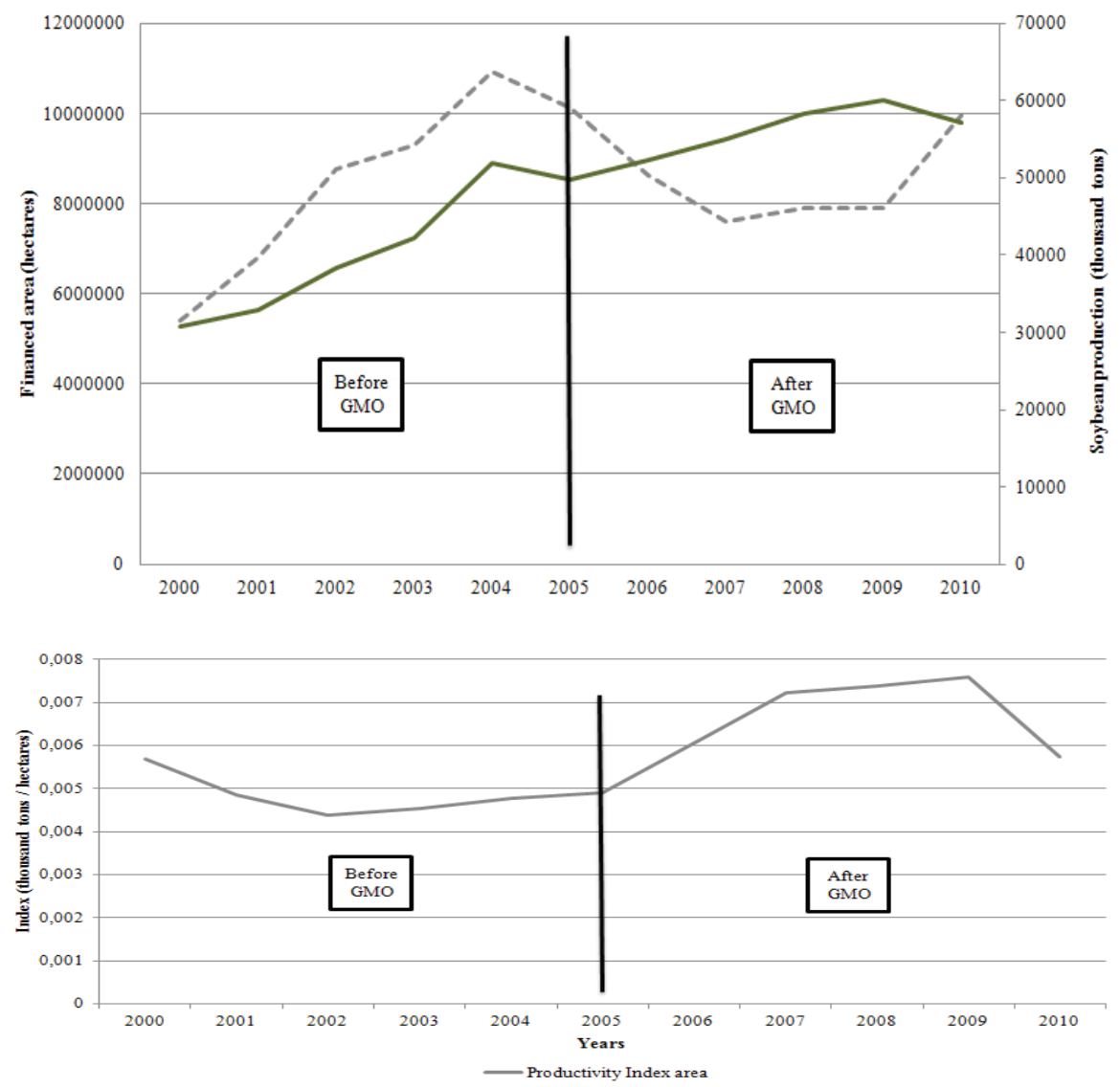

Figure 5. Financed area, soybean production and productivity area index. Source: BCB, CONAB (20II)

ISSN: 07I 8-2724. (http://www.jotmi.org)

Journal of Technology Management \& Innovation (c) Universidad Alberto Hurtado, Facultad de Economía y Negocios. 


\section{Acknowledgements}

Conselho Nacional de Desenvolvimento Científico e Tecnológico - CNPq, Coordenação de Aperfeiçoamento de Pessoal de Nível Superior - Capes.

\section{References}

Banco Central do Brasil - BCB. (20I I).Anuário estatístico de crédito rural, $B C B$ 'S website. http://www.bcb.gov.br/?REDIRELRURAL [Acessed May 23, $20 \mathrm{II}$ ].

BONNY, S. (2003). Success factors, issues and prospects for the first GM crops: the case of Roundup Ready $\AA$ soybean in the USA. Paper presented at the International Consortium on Agricultural Biotechnology Research (ICABR), Ravello, Italy.

Céleres Empresa de Consultoria - CÉLERES. (201I). Os benefícios econômicos da biotecnologia agrícola no Brasil: 1996/97a 2009/10. www.celeres.com.br/l/PressRelease2010_Economico-REV-3.pdf [Acessed May 23, $20 \mathrm{II}$ ].

COASE, R. H. (1937). The nature of the firm. Economica, 4, 386-405.

Companhia Nacional de Abastecimento - CONAB. (20II). Soja- Brasil: série histórica de produção safras 1976/1977 a 2010/20II, CONAB's website. www.conab.gov.br/conabweb/download/safra/SojaSerieHist.xls [Acessed May 23, 20II].

DAROIT, D., Nascimento, L. (2009). The Influence of the Actor Network on the Innovative Process of Transgenic Soybean in Rio Grande Do Sul, Brazil. Journal of Technology Management \& Innovation, 4(4), I50-160.

Empresa Brasileira de Pesquisa Agropecuária - EMBRAPA. (2004). A soja no Brasil, EMBRAPA's website. http://www. cnpso.embrapa.br/producaosoja/SojanoBrasil.htm [Acessed May 23, 20II].

International Service for the Acquisition of Agri-biotech Applications - ISAAA. (20I I). ISAAA in brief, ISAAA'S website. http://www.isaaa.org/inbrief/default.asp [Acessed May 23, 20II].

JAMES, C. (2009). Destaques da situação global das lavouras biotecnológicas/GM comercializadas:2009. http://www.isaaa. org/resources/publications/briefs/4I/highlights/pdf/Brief\%20 4I\%20-\%20Highlights\%20-\%20Portuguese.pdf [Acessed May 23, 20I I].
OSAKI, M., Batalha, M. O. (2007). Mudança do sistema de produção da soja com o OGM. Paper presented at the XLV Congresso da Sociedade Brasileira de Economia e Sociologia Rural, Londrina, Brasil.

PENROSE, E. (1959). The theory of the growth of the firm. Oxford University Press, New York.

RICARDO, D. (I8I7). The principles of political economy and taxation. John Murray, London.

SMITH,A. (1776). An Inquiry into the Nature and Causes of the Wealth of Nations. The Clarendon Press, Oxford.

SCHUMPETER, J. A. (1942). Capitalism, Socialism and Democracy. Unwin, London. 